\title{
Inhibitory and excitatory amino acid neurotransmitter binding sites in cynomolgus monkey ( Macaca fascicularis) cervical spinal cord
}

\author{
Roger L. Albin, Zane Hollingsworth, Sharin Y. Sakurai and Sid Gilman \\ Department of Neurology and Neuroscience Program, University of Michigan, Ann Arbor, MI 48109 (USA)
}

(Accepted 1 December 1992)

\begin{abstract}
Key words: Glutamate; $\gamma$-Aminobutyric acid; Glycine; Benzodiazepine; $N$-Methyl-D-aspartate; Quisqualate; Dorsal horn; Substantia gelatinosa; $\gamma$-Aminobutyric acid ${ }_{A} ; \gamma$-Aminobutyric $\operatorname{acid}_{B}$
\end{abstract}

\begin{abstract}
Autoradiography of inhibitory and excitatory amino acid neurotransmitter binding sites in the cervical spinal cord of $M$. fascicularis spinal cord revealed inhomogeneous distribution of all binding sites in spinal gray matter. Quisqualate-sensitive $\left[{ }^{3} \mathrm{H}\right] \mathrm{glutamate}$ binding, $\left[{ }^{3} \mathrm{H}\right] \mathrm{MK}-801 \mathrm{binding}$, benzodiazepine binding, kainate binding, and $\mathrm{GABA}_{\mathrm{B}}$ binding had highest levels in the superficial layers of the dorsal horn (laminae 1 and 2) and substantially lower levels in other laminae. $\left[{ }^{3} \mathrm{H}\right]$ Strychnine binding was more uniformly distributed throughout all laminae with highest levels in the superficial layers of the dorsal horn. These results are similar to those found in other mammals.
\end{abstract}

Excitatory amino acids (EAAs) and the inhibitory amino acids, gamma-aminobutyric acid (GABA) and glycine (GLY), are important neurotransmitters within the spinal cord. EAAs are known to be neurotransmitters of primary afferents and descending projections from the brain ${ }^{6}, 16,17,24,301$, and may be neurotransmitters of some intrinsic spinal neurons ${ }^{11,20}$. GABA and GLY are the neurotransmitters of populations of spinal interneurons ${ }^{15,26-29}$.

An important facet of both EAA- and GABA-mediated neurotransmission is the existence of receptor subtypes with distinctive pharmacologic and physologic properties. Four types of pharmacologically defined EAA receptors and two types of GABA receptors are recognized ${ }^{4,7,13,31}$. Among ionotropic EAA receptors, the $N$-methyl-D-aspartate (NMDA) receptor is distinguished by long latency, long duration depolarizations and voltage-dependent activation. NMDA receptors possess additional modulatory sites/binding sites for glycine, polyamines, and dissociative anesthetics. The $\alpha$-amino-3-hydroxy-5-methylisoxazole-4-propionic acid (AMPA) and kainate (KA) receptors are ionotropic receptors mediating conventional fast neurotransmission. The metabotropic EAA receptor is a G-protein coupled receptor linked to inositol phospholipid metabolism. Both the MET and AMPA receptors are activated by quisqualate. Two types of GABA receptors are recognized. The $\mathrm{GABA}_{-\mathrm{A}}$ receptor is a heteroligomeric ionotropic receptor with additional modulatory/binding sites for benzodiazepines ( $\mathrm{BDZ}$ ) and other compounds. The $\mathrm{GABA}_{-\mathrm{B}}$ receptor is a G-protein coupled receptor linked to modulation of ion channels and second messenger systems. Cloning of EAA and $\mathrm{GABA}_{-}$- receptors have added another level of complexity to the classification of these receptors by revealing a wealth of different proteins underlying the prior pharmacological classification schemes.

Prior studies have described the distribution of EAA, GABA, and GLY binding sites in rodent, human, and cat spinal cord ${ }^{2,8,9,12,14,18,19,29,32}$. Non-human primates are used frequently for studies of spinal and sensory function, but no study has described the distribution of these binding sites in non-human primate spinal cord. We used receptor autoradiography to describe the distribution of EAA, GABA, and GLY binding sites in the cervical spinal cord of the cynomolgus monkey ( $M$. fascicularis).

Six cynomolgus monkeys were anesthetized, sacrificed with cardioplegic doses of intravenous $\mathrm{KCl}$, and the brain and spinal cord were extracted as described 
TABLE I

$E A A, G A B A$, and $G L Y$ binding sites assays

\begin{tabular}{|c|c|c|c|c|c|c|}
\hline Site & Ligand & S.A. & Conc. & Buffer & Blockers & Blank \\
\hline $\begin{array}{l}\text { Quisqualate- } \\
\text { sensitive } \\
\text { glutamate }\end{array}$ & {$\left[{ }^{3} \mathrm{H}\right]$ glutamate } & $48 \mathrm{Ci} / \mathrm{mmol}$ & $20 \mathrm{nM}$ & $\begin{array}{l}50 \mathrm{mM} \text { Tris- } \mathrm{HCl} \\
+2.5 \mu \mathrm{M} \mathrm{CaCl}_{2} \\
\mathrm{pH} 7.2\end{array}$ & $1 \mathrm{mM}$ NMDA & $\begin{array}{l}2.5 \mu \mathrm{M} \\
\text { quisqualate }\end{array}$ \\
\hline NMDA & {$\left[{ }^{3} \mathrm{H}\right] \mathrm{MK}-801$} & $15 \mathrm{Ci} / \mathrm{mmol}$ & $20 \mathrm{nM}$ & $\begin{array}{l}50 \mathrm{mM} \text { Tris-Ac } \\
\mathrm{pH} 7.4\end{array}$ & - & $5 \mu \mathrm{M}$ MK-801 \\
\hline Kainate & {$\left[{ }^{3} \mathrm{H}\right]$ kainate } & $6 \mathrm{Ci} / \mathrm{mmol}$ & $60 \mathrm{nM}$ & $\begin{array}{l}50 \mathrm{mM} \text { Tris-Ac } \\
\text { pH } 7.2\end{array}$ & - & $100 \mu \mathrm{M}$ kainate \\
\hline $\mathrm{GABA}_{-\mathrm{A}}$ & {$\left[{ }^{3} \mathrm{H}\right]$ flunitrazepam } & $85 \mathrm{Ci} / \mathrm{mmol}$ & $5 \mathrm{nM}$ & $\begin{array}{l}50 \mathrm{mM} \text { Tris-Cit } \\
\mathrm{pH} 7.0\end{array}$ & - & $2 \mu \mathrm{M}$ clonazepam \\
\hline $\mathrm{GABA}_{\rightarrow \mathrm{B}}$ & {$\left[{ }^{3} \mathrm{H}\right] \mathrm{GABA}$} & $105 \mathrm{Ci} / \mathrm{mmol}$ & $20 \mathrm{nM}$ & $50 \mathrm{mM}$ Tris- $\mathrm{HCl}$ & $10 \mu \mathrm{M}$ isoguvacine & $100 \mu \mathrm{M}$ baclofen \\
\hline Glycine & {$\left[{ }^{3} \mathrm{H}\right]$ strychnine } & $17 \mathrm{Ci} / \mathrm{mmol}$ & $26 \mathrm{nM}$ & $50 \mathrm{mM} \mathrm{KNaPO}_{4}$ & - & $24 \mathrm{mM}$ glycine \\
\hline
\end{tabular}

previously ${ }^{23}$. Brains and spinal cords were frozen by immersion in isopentane cooled with liquid nitrogen, coated with embedding matrix and stored at $-70^{\circ} \mathrm{C}$. All animals were controls for a study of the effects of cerebral cortical ablation on motor performance. All animals received intravenous $\left[{ }^{14} \mathrm{C}\right]$ deoxyglucose prior to death ${ }^{23}$. Prewash steps removed the $\left[{ }^{14} \mathrm{C}\right]$ deoxyglucose and prevented it from interfering with analysis of binding data.

At the time of assay, spinal cords were warmed to $-20^{\circ} \mathrm{C}$ overnight and $1-\mathrm{cm}$ blocs were taken at the middle of the cervical enlargement. Twenty-micron frozen sections were cut on a Lipshaw cryostat and thaw mounted onto gelatin-coated slides. Sections were stored at $-20^{\circ} \mathrm{C}$ until the time of assay $(24-72 \mathrm{~h})$. Closely adjacent sections were fixed over paraformaldehyde vapor for $48-72 \mathrm{~h}$ and stained with $0.5 \%$ Cresyl violet.

EAA, GABA, and GLY binding sites were assayed with conventional techniques (Table I). All assays were run in duplicate or triplicate. Quisqualate-sensitive $\left[{ }^{3} \mathrm{H}\right]$ glutamate binding (a combined measure of AMPA and MET binding sites) ${ }^{3}$, GABA $_{-B}$ binding ${ }^{5}$, and $\left[{ }^{3} \mathrm{H}\right]$ kainate binding ${ }^{14}$ were all performed in a similar manner. Sections received $3 \times 10 \mathrm{~min}$ prewashes in buffer at $4^{\circ} \mathrm{C}$, dried under a stream of cool air, and immersed in cytomailers containing buffer $\left(4^{\circ} \mathrm{C}\right)$ with radioactive ligand and appropriate blocking agents. After $45 \mathrm{~min}$, incubations were terminated with 3 (GABA $_{-\mathrm{B}}$ assay) or $4\left(\left[{ }^{3} \mathrm{H}\right]\right.$ glutamate and $\left[{ }^{3} \mathrm{H}\right]$ kainate) rapid 4-ml squirts of buffer $\left(4^{\circ} \mathrm{C}\right)$ from a repipettor followed by $1\left(\mathrm{GABA}_{-\mathrm{B}}\right)$ or $2\left(\left[{ }^{3} \mathrm{H}\right]\right.$ glutamate and $\left[{ }^{3} \mathrm{H}\right]$ kainate) rapid $3 \mathrm{ml}$ squirts of $2.5 \%$ acetone in glutaraldehyde, and dried under a stream of hot air.

NMDA binding sites were assayed with $\left[{ }^{3} \mathrm{H}\right] \mathrm{MK}-801$ according to the method of Sakurai et al. ${ }^{21}$ (Table 1). Sections received $3 \times 10$ min prewashes in buffer $\left(4^{\circ} \mathrm{C}\right)$, dried under a stream of cool air, and immersed in ligand solution for $2 \mathrm{~h}$ at room temperature. Incubation was terminated by washing sections for $80 \mathrm{~min}$ in buffer $\left(4^{\circ} \mathrm{C}\right)$ and sections were dried under a stream of hot air.

$\mathrm{GABA}_{-\mathrm{A}}$ binding sites were assayed by determining $\mathrm{BDZ}$ binding with $\left[{ }^{3} \mathrm{H}\right]$ flunitrazepam ${ }^{3}$. Sections received $3 \times 10 \mathrm{~min}$ prewashes in buffer $\left(4^{\circ} \mathrm{C}\right)$, and then were dried under a stream of cool air, and immersed in ligand solution $\left(4^{\circ} \mathrm{C}\right)$ for $30 \mathrm{~min}$. Incubation was terminated by one quick dip in buffer $\left(4^{\circ} \mathrm{C}\right)$ followed by $2 \times 5$ min rinses in buffer $\left(4^{\circ} \mathrm{C}\right)$, and then sections were dried under a stream of hot air.

\section{TABLE II}

$E A A, G A B A$, and GLY binding site levels in cynomolgus monkey cervical spinal cord

All values in fmol/mg prot (S.E.M.). SDH = superficial dorsal horn, DDH = deep dorsal horn, IH = intermediate region, VH = ventral horn

\begin{tabular}{|c|c|c|c|c|}
\hline Binding site & $S D H$ & $D D H$ & $I H$ & $V H$ \\
\hline $\begin{array}{l}\text { Quisqualate- } \\
\text { sensitive } \\
\text { glutamate }\end{array}$ & $\begin{array}{ll}30 & (6.4) *\end{array}$ & 4.65 (1.6) & $2.7 \quad(1.7)$ & $2.4(1.8)$ \\
\hline NMDA & $218.2(14.4) *$ & $68.2 \quad(5.8)$ & (4.1) & $60.3(5.2)$ \\
\hline Kainate & $364.9(16.8) *$ & $68.9 \quad(5.9) * *$ & $36.9 \quad$ (4) & $18.9(4.9)$ \\
\hline $\mathrm{GABA}_{-\mathrm{A}}$ & $227.4(16.4) *$ & $110.6(10.7) * *$ & $86.3 \quad(9.4)$ & $73.9(8.7)$ \\
\hline $\mathrm{GABA}_{-\mathrm{B}}$ & $61.2(12.2) *$ & $16.2 \quad(5.4)$ & $9.4 \quad(4.1)$ & $7.5 \quad(3.6)$ \\
\hline Glycine & $3364(69) *$ & $2198 \quad(140)$ & 2206 & 2302 \\
\hline
\end{tabular}

* Significantly different than DDH, IH, VH $(P<0.05)$.

** Significantly different than IH, VH $(P<0.05)$. 
To assay GLY sites, $\left[{ }^{3} \mathrm{H}\right]$ strychnine binding was performed $^{32}$. Sections received $3 \times 10$ min prewashes in buffer $\left(4^{\circ} \mathrm{C}\right)$ and dried under a stream of cool air, and then incubated in ligand solution $\left(4^{\circ} \mathrm{C}\right)$ for $30 \mathrm{~min}$. Incubation was terminated with 4 quick dips in buffer $\left(4^{\circ} \mathrm{C}\right)$ followed by one quick dip in distilled water. Sections were dried under a stream of hot air.

Slides were apposed to tritium sensitive film (Hyperfilm, Amersham) and exposed along with standards containing known amounts of radioactivity (ARC, St Louis, MO) for 1-3 weeks. Films were developed in D-19 (Kodak) and binding levels were quantitated with computer assisted densitometry using the MCID system (Imaging Research, St. Catharines, ONT). Regions read included the superficial dorsal horn (SDH), comprising laminae 1 and 2; the deep dorsal horn (DDH), comprising laminae 3 to 5 ; the intermediate region (IN), comprising lamina 6 , lamina 10 , and part of lamina 7; and the ventral horn (VH). Assignment of regions was made by referring to Cresyl violet-stained sections. Binding site levels across regions were com-
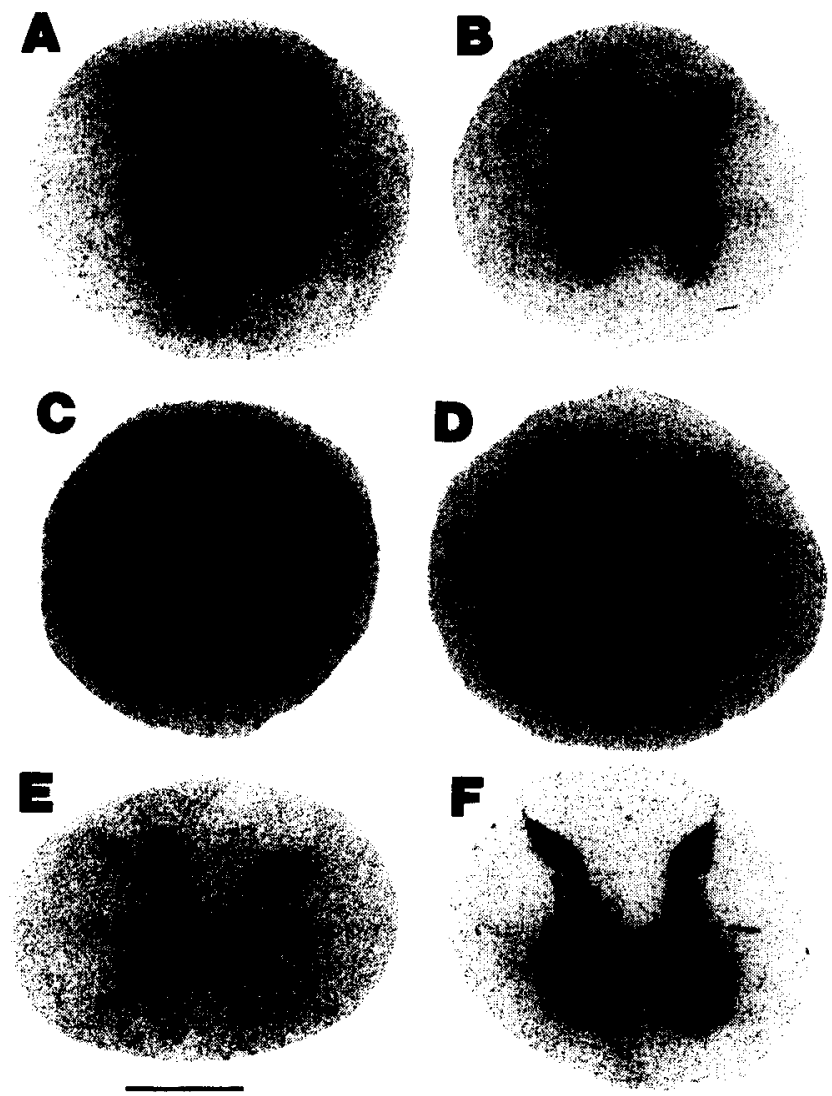

Fig. 1. Excitatory and inhibitory amino acid neurotransmitter receptor binding sites in the cynomologus monkey cervical spinal cord. A quisqualate-sensitive $\left[{ }^{3} \mathrm{H}\right]$ glutamate binding. $\mathrm{B}\left[{ }^{3} \mathrm{H}\right] \mathrm{MK}-801$ binding. $\mathrm{C}\left[{ }^{3} \mathrm{H}\right]$ kainate binding. $\mathrm{D}\left[{ }^{3} \mathrm{H}\right]$ Flunitrazepam binding. E GABA $-\mathrm{B}$ binding. $\mathrm{F}\left[{ }^{3} \mathrm{H}\right]$ Strychnine binding. $\mathrm{SDH}=$ superficial dorsal horn (laminae 1 and 2), DDH = deep dorsal horn (laminae 3-5), IH = intermediate spinal gray (laminae 6,10 and part of 7), $\mathrm{VH}=$ ventral horn. Bar $=2 \mathrm{~mm}$. pared with a one-factor ANOVA using the Statview II program (Abacus Concepts, Berkeley, CA) followed by Fisher's PLSD test for post-hoc individual comparisons.

Data analysis revealed that all binding sites had a heterogeneous distribution within the spinal gray matter (Table II, Fig. 1). Quisqualate-sensitive $\left[{ }^{3} \mathrm{H}\right]$ glutamate binding, $\left[{ }^{3} \mathrm{H}\right]$ kainate binding, $\mathrm{BDZ}$ binding, $\mathrm{GABA}_{-\mathrm{B}}$ binding, and $\left[{ }^{3} \mathrm{H}\right] \mathrm{MK}-801$ binding were all concentrated within the SDH with significantly lower levels of binding in other regions (Table II, Fig. 1). The IN and $\mathrm{VH}$ had especially low levels of all binding sites (Table II, Fig. 1). BDZ binding and $\left[{ }^{3} \mathrm{H}\right]$ kainate binding had higher levels in the DDH than the IX or VH. GLY binding sites were more homogeneously distributed with substantial levels of $\left[{ }^{3} \mathrm{H}\right]$ strychnine binding in all regions (Table II, Fig. 1). Nonetheless, GLY binding site levels were highest in the SDH (Table II, Fig. 1).

These results are similar to prior results of binding studies in rat, mouse, cat, and human spinal cord. In all cases, both EAA and GABA binding sites have been found to be concentrated in the superficial dorsal horn, especially lamina $2^{2,9,12,14,18,29}$. similarly, GLY binding sites have been found to be more evenly distributed throughout the spinal gray, though highest levels are generally found in the superficial dorsal horn ${ }^{8,19,32}$. For EAA binding sites, these data are similar to the results of Tallaksen-Greene et al. in the trigeminal nucleus, the brainstem homologue of the dorsal horn ${ }^{25}$.

These results also have some correlation with the distribution of EAAs and GABA within the spinal cord. EAAs are neurotransmitters released by primary and descending afferents, which have extensive terminal arborizations within the $\mathrm{SDH}^{6,16,17,24,30}$. Intrinsic EAAergic spinal neurons may also be concentrated within laminae 1 and $2^{11,20}$. These results also correlate well with electrophysiologic data showing that EAA-responsive dorsal horn neurons are concentrated in the superficial laminae, where they may play a particularly important role in the transfer of nociceptive information to the central nervous system ${ }^{1,22,24}$. The distribution of GABAergic innervation also has some correlation with the distribution of $\mathrm{GABA}_{-\mathrm{A}}$ and $\mathrm{GABA}_{-\mathrm{B}}$ binding sites. Spinal GABAergic interneurons are abundant within the superficial laminae, particularly within laminae 1 and $2^{15,27,29}$. Glutamic acid decarboxylase immunoreactivity is concentrated within the superficial layers of the dorsal horn, with highest density in laminae 2 and high levels in both laminae 3 and $4^{15}$ $\mathrm{GABA}_{B}$ receptors are found both as postsynaptic receptors on neurons within the superficial laminae of 
dorsal neurons and as presynaptic heteroreceptors on the terminals of primary afferents within the dorsal horn ${ }^{10,18}$.

The distribution of GLY binding sites does not, however, match precisely the distribution of GLYinergic neuronal elements in the spinal cord. While GLYimmunoreactive neurons and neuropil are found throughout the spinal gray, GLY-immunoreactive neurons and neuropil tend to have lower density in laminae 1 and 2, a distribution somewhat different than that found with $\left[{ }^{3} \mathrm{H}\right]$ strychnine binding ${ }^{26,27,28}$.

Other neurotransmitter/neuromodulator receptor binding sites have been found to be concentrated within the SDH. The concentration of different neurotransmitter receptor binding sites within the superficial dorsal horn indicates that processing of afferent input within this region is likely to be complex.

This work was supported by NS01300 and NS19613.

1 Aanonsen, L.M., Lei, S. and Wilcox, G.L., Excitatory amino acid receptors and nociceptive neurotransmission in rat spinal cord, pain, 41 (1990) 309-321.

2 Aanonsen, L.M. and Seybold, V.S., Phencyclidine and sigma receptors in rat spinal cord: binding characterization and quantitative autoradiography, Synapse, 4 (1989) 1-10.

3 Albin, R.L. and Gilman, S., Autoradiographic localization of inhibitory and excitatory amino acid neurotransmitter receptors in human normal and olivopontocerebellar atrophy cerebellar cortex, Brain Res., 522 (1990) 37-45.

4 Bowery, N., GABA - B receptors and their significance in mammalian pharmacology, Trends Pharmacol. Sci., 10 (1989) 401-407.

5 Chu, D.C.M., Albin, R.L., Young, A.B. and Penney, J.B., Distribution and kinetics of GABA $_{-\mathrm{B}}$ binding sites in rat central nervous system: a quantitative autoradiographic study, Neuroscience, 34 (1990) 341-357.

6 De Biasi, S. and Rustioni, A., Glutamate and substance P coexist in primary afferent terminals in the superficial laminae of spinal cord, Proc. Natl. Acad. Sci. USA, 85 (1988) 7820-7824.

7 Enna, S.J. GABA ${ }_{-A}$ Receptors. In: R.F. Squires, (Ed.), $G A B A$ and Benzodiazepine Receptors, CRC Press, R.F. Boca Raton, FL, 1988, pp. 91-106.

8 Frostholm, A. and Rotter, A., Glycine receptor distribution in mouse CNS autoradiographic localization of $\left[{ }^{3} \mathrm{H}\right]$ strychnine, Brain. Res. Bull., 15 (1985) 473-486.

9 Jansen, K.L.R., Faull, R.L.M., Dragunow, M. and Waldvogel, H., Autoradiographic localisation of NMDA, quisqualate and kainic acid receptors in human spinal cord, Neurosci. Lett., 108 (1990) $53-57$.

10 Kangrga, I., Jiang, M. and Randic, M., Actions of (-)-baclofen on rat dorsal horn neurons, Brain Res., 562 (1991) 265-275.

11 Miller, K.E., Clements, J.R., Larson, A.A. and Beitz, A.J., Organization of glutamate-like immunoreactivity in the rat superficial dorsal horn: light and electron microscopic observations, Synapse, 2 (1988) 28-36.

12 Mitchell, J.J. and Anderson, K.J., Quantitative autoradigraphic analysis of excitatory amino acid receptors in the cat spinal cord, Neurosci. Lett., 124 (1991) 269-272.

13 Monaghan, D.T., Bridges, R.J. and Cotman, C.W., The excitatory amino acid receptors: their classes, pharmacology and distinct properties in the function of the central nervous system, $A n n u$. Rev. Pharmacol. Toxicol., 29 (1989) 365-402.

14 Monaghan, D.T. and Cotman, C.W., The distribution of $\left[{ }^{3} \mathrm{H}\right] \mathrm{kainic}$ acid binding in rat CNS as determined by autoradiography, Brain Res., 252 (1982) 91-100.

15 Mugnaini, E. and Oertel, W.H. An atlas of the distribution of GABAergic neurons and terminals in the rat CNS as revealed by CAD immunocytochemistry in the rat. In: A. Björklund and T. Hökfelt, Handbook of Chemical Neuroanatomy, GABA and Neuropeptides in the CNS, Vol. 4, Part I, Elsevier, Amsterdam, 1985, pp. 436-508.

16 Potashner, S.J., Dymczyk, L. and Deangelis, M.M., D-aspartate uptake and release in the guinea pig spinal cord after partial ablation of the cerebral cortex, J. Neurochem., 50 (1988) 103-111.

17 Potashner, S.J. and Tran, P.L., Decreased uptake and release of D-aspartate in the guinea pig spinal cord after dorsal root section, J. Neurochem., 42 (1984) 1135-1144.

18 Price, G.W., Kelly, J.S. and Bowery, N.G., The location of GABA-B receptor binding sites in mammalian spinal cord, Synapse, 1 (1987) 530-538.

19 Probst, A., Cortes, R. and Palacios, J.M., The distribution of glycine receptors in the human brain a light microscopic autoradiographic study using $\left[{ }^{3} \mathrm{H}\right]$ strychnine, Neuroscience, 17 (1986) $11-35$.

20 Rustioni, A. and Cuenod, M., Selective retrograde transport of D-aspartate in spinal interneurons and cortical neurons of rats, Brain Res., 236 (1982) 143-155.

21 Sakurai, S.Y., Cha, J.J., Penney, J.B. and Young, A.B., Regional distribution and properties of $\left[{ }^{3} \mathrm{H}\right] \mathrm{MK}-801$ binding sites determined by quantitative autoradiography in rat brain, Neuroscience, 40 (1991) 533-543.

22 Schneider, S.P. and Perl, E.R., Comparison of primary afferent and glutamate excitation of neurons in the mammalian spinal dorsal horn, J. Neurosci., 8 (1988) 2062-2073.

23 Shimoyama, I., Dauth, G.W., Gilman, S., Frey, K.A. and Penney Jr., J.B., Thalamic, brainstem and cerebellar glucose metabolism in the hemiplegic monkey, Ann. Neurol., 24 (1988) 718-726.

24 Skilling, S.R., Smullin, D.N., Beitz, A.J. and Larson, A.A., Extracellular amino acid concentrations in the dorsal spinal cord of freely moving rats following veratridine and nociceptive stimulation, J. Neurochem., 51 (1988) 127-132.

25 Tallaksen-Greene, S.J., Young, A.B., Penney, J.B. and Beitz, A.J., Excitatory amino acid binding sites in the trigeminal principal sensory and spinal trigeminal nuclei of the rat, Neurosci. Lett., 141 (1992) 79-83.

26 Todd, A.J., An electron microscope study of glycine-like immunoreactivity in laminae I-III of the spinal dorsal horn of the rat, Neuroscience, 39 (1990) 387-394.

27 Todd, A.J. and Sullivan, A.C., Light microscope study of the coexistence of GABA-like and glycine-like immunoreactivities in the spinal cord of the rat, J. Comp. Neurol., 296 (1990) 496-505.

28 van den Pol, A.T. and Gorcs, T., Glycine and glycine receptor immunoreactivity in brain and spinal cord, J. Neurosci., 8 (1988) $472-492$.

29 Waldvogel, N.J., Faull, R.L.M., Jansen, K.L.R. et al., GABA, GABA receptors and benzodiazepine receptors in the human spinal cord: an autoradiographic and immunohistochemical study at the light and electron microscopic levels, Neuroscience, 39 (1990) 361-385.

30 Young, A.B., Bromberg, M.B. and Penney, J.B., Decreased glutamate uptake in subcortical areas deafferented by, sensorimotor cortical ablation in the cat, J. Neurosci, 1 (1981) 241-249.

31 Young, A.B. and Fagg, G.E., Excitatory amino acid receptors in the brain: membrane binding and receptor autoradiographic appraoches, Trends Pharmacol. Sci., 11 (1990) 126-133.

32 Zarbin, M.A., Wamsley, J.K. and Kuhar, M.J., Glycine receptor: light microscopic autoradigraphic localization with $\left[{ }^{3} \mathrm{H}\right]$ strychnine, J. Neurosci., 1 (1981) 532-547. 